20. Litonjua L A, Bush P J, Andreana S, Tobias T S, Cohen $R$ E. Effects of occlusal load on cervical lesions. J Oral Rehabil 2004; 31: 225-232.

21. Walter C, Kress E, Gotz H, Taylor K, Willershausen I, Zampelis A. The anatomy of non-carious cervical lesions. Clin Oral Investig 2014; 18: 139-146. doi: 10.1007/ s00784-013-0960-0960.

22. Tsiggos N, Tortopidis D, Hatzikyriakos A, Menexes G. Association between self-reported bruxism activity and occurrence of dental attrition, abfraction, and occlusal pits on natural teeth. J Prosthet Dent 2008; 100: 41-46. DOI: 10.1016/S0022-0023913(08)60135=3

23. Ommerborn M A, Schneider C, Giraki M, Schafer R, Singh P, Franz M, Raab W H M. In vivo evaluation of noncarious cervical lesions in sleep bruxism subjects. J Prosthet Dent 2007; 98: 150-158. DOI: 10.1016/ S0022-0023913(07)60048-1.

24. Alvarez-Arenal A, Alvarez-Menendez L, GonzalezGonzalez I, Alvarez-Riesgo J A, Brizuela-Velasco A, deLlanos-Lanchares H. Non-carious cervical lesions and risk factors: a case-control study. J Oral Rehabil 2019; 46: 65-75. DOI: 10.1111/joor.12721.

25. Pintado M, DeLong R, Ko C, Sakaguchi R, Douglas $W$. Correlation of noncarious cervical lesion size and occlusal wear in a single adult over a 14-year time span. J Prosthet Dent 2000; 84: 436-443.
26. Jiang H, Du M Q, Huang W, Peng B, Bian Z, Tai B J. The prevalence of and risk factors for non-carious cervical lesions in adults in Hubei Province, China. Community Dent Health 2011; 28: 22-28.

27. Bader J, Mcclure F, Scurria M, Shugars D, Heymann $\mathrm{H}$. Case-control study of non-carious cervical lesions, Community Dent Oral Epidemiol 1996: 28: 286-291.

28. Que K, Guo B, Jia Z, Chen Z, Yang J, Gao P. A cross-sectional study: Non-carious cervical lesions, cervical dentine hypersensitivity and related risk factors. J Oral Rehabil 2013; 40: 24-32. DOI: 10.1111/j.1365-2842.2012.02342.x.

29. Takehara J, Takano T, Akhter R, Morita M. Correlations of noncarious cervical lesions and occlusal factors determined by using pressure-detecting sheet. J Dent 2008; 36: 774-779. DOI: 10.1016/j. jdent. 2008.05.009.

30. Bartlett D W, Lussi A, West N X, Bouchard P, Sanz M Bourgeois D. Prevalence of tooth wear on buccal and lingual surfaces and possible risk factors in young European adults. J Dent 2013; 41: 1007-1013. DOI: 10.1016/j.jdent.2013.08.018.

31. Senna P, Del Bel Cury A, Rösing C. Non-carious cervical lesions and occlusion: A systematic review of clinical studies. J Oral Rehabil 2012; 39: 450-462. doi: 10.1111/j.1365-2842.2012.02290.x
32. Silva A G, Martins C C, Zina L G et al. The association between occlusal factors and noncarious cervical esions: A systematic review. J Dent 2013; 41: 9-16. DOI: 10.1016/j.jdent.2012.10.018

33. Kaidonis J A. Tooth wear: the view of the anthropologist. Clin Oral Investig 2008; 12: 21-26. DOI: 10.1007/ s00784-007-0154-0158.

34. Aaron G M. The prevalence of non-carious cervical lesions in modern and ancient american skulls: lack of evidence for an occlusal etiology. University of Florida, Thesis, 2004

35. Aubry M, Mafart B, Donat B, Brau J J. Brief communication: Study of noncarious cervical tooth lesions in samples of prehistoric, historic, and modern populations from the South of France. Am J Phys Anthropol 2003; 121: 10-14. DOI: 10.1002/ ajpa.10210.

36. Kieser J A, Dennison K J, Kaidonis J A, Huang D, Herbison P G P, Tayles N G. Patterns of dental wear in the early Maori dentition. Int J Osteoarchaeol 2001: 11: 206-217. DOI: 10.1002/0a.534

37. Urzúa I, Cabello R, Rodríguez G, Sánchez J, Faleiros $\mathrm{S}$, Pacheco A. Absence of non-carious cervical lesions (NCCLs) in a Chilean pre-Columbian sample with severe occlusal tooth wear. Int J Odontostomatol 2015; 9: 59-64.

\title{
Correction to: CariesCare practice guide: consensus on evidence into practice
}

The original article can be found online at https://doi.org/10.1038/s41415-019-0678-8.

Author's correction note: Clinical article Br Dent J 2019; 227: 353-362.

When this article was initially published, one of the boxes in Figure 6 had been duplicated. The correct figure is shown below:

Also, Matteo Basso's affiliation in the Acknowledgements section was incorrect. It should have read 'Matteo Basso, University of Milano, Italy'. The authors apologise for any confusion caused by these errors.

\section{Fig. 6 Tooth-preserving and patient-level prevention and control fowchart}

\section{DO}

Tooth-preserving \& patient level prevention and control

\begin{tabular}{|c|c|}
\hline \multicolumn{2}{|c|}{ Management at the Patient Level } \\
\hline Homecare approaches & Clinical interventions/approaches \\
\hline For all patients & For high risk patients \\
\hline $\begin{array}{l}\text { Toothbrushing } 2 / \text { day with a fluoride } \\
\text { toothpaste }(\geq 1.100 \mathrm{ppm} P \text { ) following } \\
\text { the dental team instructions }\end{array}$ & $\begin{array}{c}\text { Motivational engagement of } \\
\text { patients to improve oral health } \\
\text { behaviours } \\
\text { (oral hygiene and diet/sugars) }\end{array}$ \\
\hline $\begin{array}{l}\text { For high risk patients } \\
\text { (in addition) }\end{array}$ & $\begin{array}{l}2-4 / \text { year fluoride } \\
\text { varnish/gel/solution after } \\
\text { tooth cleaning }\end{array}$ \\
\hline $\begin{array}{c}\text { Using a higher efficacy } \\
\text { fluoride toothpaste } \\
(\geq 1,450 \text { ppm } P \text { or high } P \text { prescription) }\end{array}$ & $\begin{array}{l}\text { Sealing of risk surfaces } \\
\text { (after assessment of need) }\end{array}$ \\
\hline $\begin{array}{l}\text { General behaviour modification } \\
\text { in oral health }\end{array}$ & \\
\hline$M$-intain dantal vi & isk-based intervals \\
\hline
\end{tabular}

\begin{tabular}{c|c|c|}
$\begin{array}{c}\text { Active } \\
\text { monitoring and } \\
\text { reassessment }\end{array}$ & $\begin{array}{c}\text { Fluoride varnish/gel. } \\
\text { application on specific } \\
\text { lesions }\end{array}$ \\
Sealing \\
Instructions on localised \\
mechanical biofilm removal
\end{tabular} \mid $\begin{gathered}\text { Tooth-preservative restorations } \\
\text { Selective carious tissue removal/ } \\
\text { pulp preserving restorations } \\
\text { (including Hall technique / ART/ } \\
\text { Sealing cavities) }\end{gathered}$

Note: this figure is an illustration, not a specific prescription 